\title{
LKPD BERBASIS DISCOVERY LEARNING BERDASARKAN KERAGAMAN KURA-KURA SUMATERA DI UNIVERSITAS BENGKULU
}

\author{
Anisa Bella ${ }^{{ }^{*}}$, Yennita $^{1}$, Aceng Ruyani ${ }^{2}$ \\ ${ }^{1}$ Program Pendidikan Biologi, Fakultas Keguruan dan Ilmu Pendidikan Universitas Bengkulu \\ ${ }^{1}$ Program Pasca Sarjana Pendidikan IPA FKIP Universitas Bengkulu \\ Email:bellaanisa97@gmail.com
}

\begin{abstract}
Abstrak
Penelitian ini bertujuan untuk: 1) mengetahui kelayakan LKPD berbasis Discovery Learning (DL) berdasarkan keragaman kura-kura Sumatera di Universitas Bengkulu 2) Menilai hasil belajar (kognitif) peserta didik melalui kegiatan indoor-outdoor-indoor (IOI) menggunakan LKPD hasil pengembangan. Kelayakan LKPD diketahui dari hasil validasi dosen dan guru Biologi SMA serta uji keterbacaan LKPD pada peserta didik. Penilaian kognitif peserta didik menggunakan tes tertulis berupa posttest yang diberikan pada pembelajaran dengan menerapkan strategi pembelajaran IOI menggunakan LKPD yang dikembangkan. Hasil penelitian menujukkan bahwa persentase validasi LKPD yang diperoleh yaitu $84,37 \%$ dengan kategori sangat valid. Desain LKPD juga dikatakan layak dari hasil uji keterbacaan oleh siswa dengan nilai 90,93\%. Kemampuan kognitif peserta didik dalam menggunakan LKPD juga mengalami peningkatan dengan nilai rata-rata posttest sebesar 81,2. Sedangkan ketuntasan klasikal yang diperoleh yaitu 78,26\%. Hasil penelitian menyimpulkan bahwa LKPD berbasis discovery learning layak digunakan sebagai bahan ajar siswa serta dapat meningkatkan kemampuan kognitif siswa.
\end{abstract}

Kata kunci: Pengembangan LKPD, Kura-kura Sumatera, R\&D

\begin{abstract}
The type of research used was research and development (R \& D). This study aimed to: 1) Know the feasibility of developing LKPD based on Discovery Learning based on the diversity of Sumatran turtles 2) Assessing learning outcomes (cognitive) of students through indoor-outdoor-indoor activities (IOI) using development LKPD. Whether or not the worksheet is developed, the results of the development are known from the results of the validation of high school Biology lecturers and teachers as well as the LKPD readability test for students. Cognitive assessment of students using a written test in the form of posttest given to learning with the IOI strategy using LKPD as a result of development. Validation results are declared very feasible with a value of $84.37 \%$ with a very valid category. The LKPD design is also said to be worthy of $90.93 \%$ with readability testing by 23 students in Muhammadiyah 4 High School in Bengkulu City. Cognitive learners experience an increase. The acquisition of the posttest average value is 81.2 . The classical completeness obtained is $78.26 \%$, has reached completeness.
\end{abstract}

Keywords: Development of LKPD, Sumatran Turtles, R \& D 


\section{PENDAHULUAN}

Bahan ajar merupakan seperangkat materi yang disusun secara sistematis baik tertulis maupun tidak sehingga mampu lingkungan atau suasana yang memungkinkan peserta didik untuk belajar. Melalui bahan ajar, peserta didik dapat mempelajari suatu kompetensi secara runtut dan sistematis sehingga secara garis besar mampu menguasai semua kompetensi. Bahan ajar dapat diimplementasikan pada semua mata pelajaran, salah satunya adalah mata pelajaran Biologi (Yeni, 2018). Menurut Munandar (2016), LKPD berperan sebagai salah satu bahan ajar yang seharusnya dibuat oleh ahli atau guru mata pelajaran supaya isi dan juga tujuan pembelajaran dapat tercapai.

Berdasarkan hasil wawancara yang dilakukan dengan guru Biologi di SMA Muhammadiyah 4 Kota Bengkulu, belum terdapat LKPD berbasis Discovery Learning $(D L)$ yang digunakan selama kegiatan pembelajaran biologi. Discovery Learning merupakan model pembelajaran yang mengarahkan peserta didik untuk dapat memahami konsep dengan cara menemukan pengetahuannya sendiri dan terlibat aktif dalam proses pembelajaran (Kemendikbud, 2014).

LKPD berbasis DL dapat digunakan pada mata pelajaran Biologi dengan mengacu pada Kompetensi Dasar 3.2 yaitu menganalisis berbagai tingkat keanekaragaman hayati beserta ancaman. Salah satu bentuk kenekaragaman hayati adalah keragaman kura-kura Sumatera. Universitas Bengkulu (UNIB) merupakan salah satu wilayah yang memiliki area konservasi kura-kura Sumatera, yaitu Turtle Learning Center (TLC). Menurut Mar'iska (2010) kura-kura di dunia berjumlah tidak kurang dari 260 spesies. Jumlah kura-kura yang hidup di Indonesia sekitar 45 spesies. Terdapat 15 jenis kurakura air tawar dan kura-kura darat yang pernah hidup di Sumatera (Iskandar 2000).

Adapun lima jenis kura-kura Sumatera yang telah dikonservasi di UNIB yaitu kura-kura Garis Hitam (Cylemys odhamii), Batok (Coura amboinensis), Pipi Putih (Siebenrockiella crassicolis) Duri/Nanas (Hoesemys spinosa) dan Baning Coklat (Manouria emys) (Wiryono dkk, 2016).

LKPD ini selanjutnya akan diujicobakan menggunakan strategi Indoor-Outdoor-Indoor (IOI). IOI merupakan kegiatan pembelajaran yang tidak hanya dilakukan di dalam kelas saja. Kegiatan pembelajaran IOI yang melibatkan lingkungan terbuka bersifat konkret sehingga kegiatan IOI diharapkan menjadikan pembelajaran peserta didik dapat lebih bermakna (Sari, 2018).

\section{METODE}

Jenis penelitian ini yaitu Penelitian dan Pengembangan (Research and Developmen). Langkah-langkah penelitian ini mengacu pada model pengembangan Sugiyono (2012) terdiri atas sepuluh langkah yaitu 1) potensi dan masalah; 2) pengumpulan data; 3) desain produk; 4) validasi desain; 5) revisi desain; 6) ujicoba produk; 7) revisi produk; 8) ujicoba pemakaian; 9) revisi produk; dan 10) produksi masal. Namun karena keterbatasan peneliti, maka dalam penelitian ini hanya dilakukan hingga langkah ke-7.

Subjek penelitian adalah peserta didik kelas X IPA 1 SMA Muhammadiyah 4 Kota Bengkulu berjumlah 23 orang, serta 3 orang validator. Instrumen yang digunakan untuk menilai hasil belajar berupa tes tertulis. Instrumen untuk mengetahui kevalidan LKPD yang telah dikembangkan peneliti adalah lembar angket validasi dan lembar uji keterbacaan. Penilaian validasi meliputi aspek kalayakan isi, kebahasaan, 
kegrafisan, dan penyajian (Depdiknas, 2008). Validasi LKPD dilakukan oleh dua dosen ahli dan satu guru biologi. Sedangkan uji keterbacaan dilakukan oleh peserta didik kelas $X$ IPA 1 SMA Muhammadiyah 4 Kota Bengkulu berjumlah 23 orang. Analisis hasil validasi dilakukan dengan menghitung skor ratarata dari setiap aspek dengan menggunakan rumus sebagai berikut:

Persentase $=\frac{\text { Jumlah skor lembar validasi }}{\text { Skor maksimal }} \times 100 \%$

Data kuantitatif yang diperoleh selanjutnya diubah menjadi data kualitatif dengan memperhatikan kriteria penilaian hasil validasi yang dapat dilihat pada Tabel 1.

Tabel 1. Kriteria Penilaian Hasil Validasi

\begin{tabular}{cc}
\hline Persentase & Kriteria \\
\hline $81-100$ & Sangat valid \\
$61-80$ & Valid \\
$41-60$ & Cukup valid \\
$21-40$ & Kurang valid \\
$0-20$ & Sangat tidak valid \\
\hline
\end{tabular}

LKPD berbasis $D L$ diuji cobakan menggunakan strategi $I O I$ yang terdiri dari 3 tahap yaitu indoor 1, outdoor, dan indoor 2. Pada tahap uji coba LKPD digunakan untuk mengukur hasil belajar peserta didik. Data hasil ketuntasan belajar siswa yang diperoleh dari tes peserta didik digunakdighitung dengan rumus:

$$
\% \mathrm{~KB}=\frac{n}{N} x 100 \%
$$

(Sugiyono, 2012)
Keterangan :

$\mathrm{KB}=$ ketuntasan belajar secara klasikal $(\geq 75 \%)$

$\mathrm{n}$ = jumlah siswa yang mendapatkan nilai di atas $K K M \geq 75$

$\mathrm{N}$ = jumlah seluruh peserta didik

\section{HASIL DAN PEMBAHASAN}

Uji validasi LKPD dilakukan oleh dua dosen ahli dan guru Biologi. Aspek yang dinilai yaitu isi, penyajian, kebahasaan, dan kegrafisan. Hasil validasi dapat dilihat pada Tabel 2.

Tabel 2. Hasil Validasi LKPD

\begin{tabular}{cccc}
\hline $\begin{array}{c}\text { Aspek } \\
\text { Penilaian }\end{array}$ & $\begin{array}{c}\text { Skor } \\
\text { rata-rata }\end{array}$ & Persentase & Kriteria \\
\hline Kelayakan & 16 & $80 \%$ & \\
Isi & 9,5 & $79,16 \%$ & Sangat \\
$\begin{array}{c}\text { Penyajian } \\
\text { Kebahasaan }\end{array}$ & 16,5 & $82,50 \%$ & Valid \\
$\begin{array}{c}\text { Kegrafisan } \\
\text { Rerata }\end{array}$ & 11,5 & $95,83 \%$ & \\
Keseluruhan & 55 & $84,37 \%$ & \\
\hline
\end{tabular}

Hasil validasi LKPD menujukkan bahwa LKPD termasuk ke dalam kriteria sangat valid, namun terdapat dengan beberapa saran perbaikan yang harus dilakukan terhadap LKPD. Saran validator berfungsi untuk memperbaiki kekurangan yang terdapat di dalam LKPD. Adapun bagian LKPD sebelum dan sesudah revisi dapat dilihat pada Tabel 3. 
Tabel 3. Perbedaan LKPD Revisi Dan Sesudah

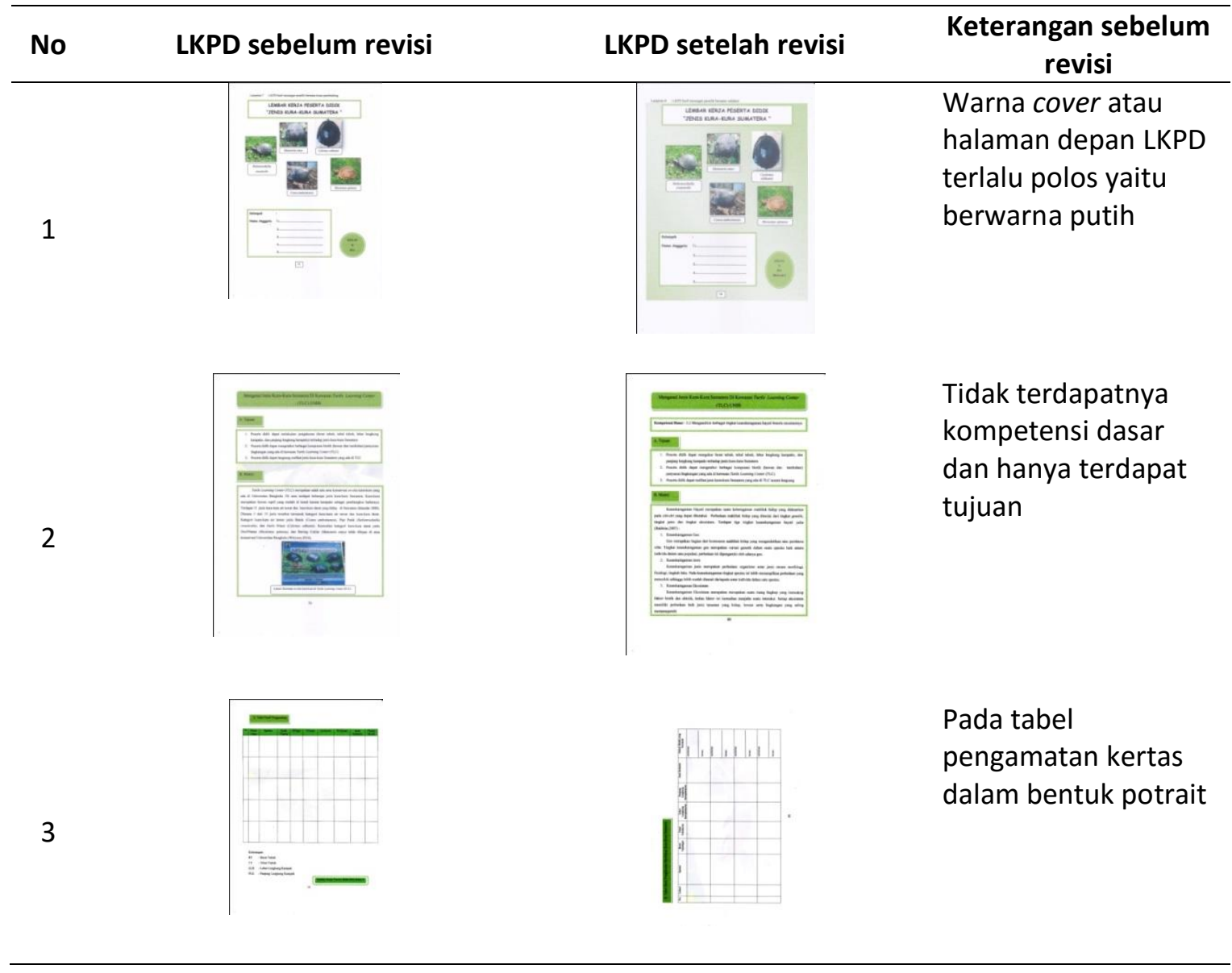

Hasil uji keterbacaan LKPD oleh peserta didik memperoleh persentase ratarata secara keseluruhan sebesar 90,93\% yang termasuk ke dalam kategori "sangat valid". Adapun hasil analisis uji keterbacaan disajikan dalam Tabel 4.

Tabel 4. Hasil Perhitungan Data Uji Keterbacaan

\begin{tabular}{cccc}
\hline $\begin{array}{c}\text { Aspek } \\
\text { Penilaian }\end{array}$ & $\begin{array}{c}\text { Skor } \\
\text { rata- } \\
\text { rata }\end{array}$ & Persentase & Kriteria \\
\hline Materi & 2,60 & 86,95 & \\
Penyajian & 2,69 & 89,85 & Sangat \\
Bahasa & 2,65 & 88,40 & Valid \\
Tampilan & 2,95 & 95,55 & \\
Rerata & 10,89 & 90,93 & \\
\hline
\end{tabular}

Setelah dilakukan tahap validasi dan

uji keterbacaan, maka peneliti mengimplementasikan LKPD untuk mengetahui hasil belajar kognitif peserta didik. Implementasi LKPD dilaksanakan melalui kegiatan IOI di kelas X IPA 1 SMA Muhammadiyah 4 Kota Bengkulu. Adapun jumlah peserta didik dalam kelas yaitu 23 orang. Implementasi LKPD terhadap aspek kognitif dilakukan secara individu dan kelompok. Pada saat implementasi pembelajaran, peserta didik akan berikan tes hasil belajar. Menurut Riduwan (2015), tes merupakan serangkaian pertanyaan yang digunakan untuk mengukur keterampilan, pengetahuan ataupun kemampuan yang dimiliki individu atau kelompok. Tes diberikan di akhir pembelajaran (posttest), tes terdiri dari 3 butir pertanyaan. 
Penggunaan LKPD dilakukan dengan menggunakan strategi IOI yang terdiri dari indoor 1, outdoor, dan indoor 2. Pada kegiatan indoor 1, pembelajaran dilakukan di dalam kelas. Menurut Zukmadini, dkk (2018) ditahap indoor 1 terdapat fase introduksi yaitu kegiatan menggali pengetahuan awal siswa. Pada tahap ini guru memperkenalkan fenomena, isu, atau permasalahan yang ada di sekitar peserta didik. Hal ini bertujuan untuk menarik perhatian siswa sehingga diketahui hal-hal apa saja yang dapat dipelajari oleh siswa dari lingkungannya.

Kegiatan selanjutnya yaitu kegiatan outdoor, dimana kegiatan ini dilakukan di luar kelas yang berlokasi di tempat konservasi kura-kura TLC Universitas Bengkulu. Menurut Utami (2014) Outdoor study adalah suatu pembelajaran di luar kelas dan mempunyai sifat yang menyenangkan, kegiatan ini memberikan kesempatan kepada peserta didik untuk mengembangkan potensi dirinya. Dalam penelitian yang dilakukan terdapat beberapa tahapan atau langkah-langkah pembelajaran yang dilaksanakan yaitu stimulasi/pemberian rangsangan, identifikasi masalah dan pengumpulan data. Setelah kegiatan outdoor dilaksanakan, selanjutnya peserta didik kembali melanjutkan kegiatan pembelajaran di dalam kelas (indoor 2). Pada tahap ini guru mereview kembali hasil pembelajaran yang telah dilakukan siswa saat pembelajaran di luar kelas (outdoor). Hal ini sesuai dengan pendapat Zukmadini (2018) yang menyatakan bahwa pada tahap indoor 2, peserta didik diminta kembali untuk masuk ke dalam kelas dan melakukan kegiatan interprestasi. Peserta didik diminta untuk mempresentasikan hasil yang diperolehnya pada saat kegiatan outdoor. Hal ini yang bertujuan untuk memverifikasi data yang telah diperoleh di lapangan. Selanjutnya siswa dan guru secara bersama-sama melakukan pembahasan konsep yang dipelajari. Data perolehan nilai hasil belajar (kognitif) peserta didik dapat dilihat Tabel 5.

Tabel 5. Hasil Belajar Kognitif Implementasi LKPD Secara Kelompok

\begin{tabular}{cccc}
\hline No. & Kelompok & Nilai & Kriteria \\
\hline 1 & I & 90 & Sangat baik \\
2 & II & 90 & Sangat baik \\
3 & III & 80 & Baik \\
4 & IV & 75 & Baik \\
& Rerata & $\mathbf{8 3 , 7 5}$ & Sangat baik \\
\hline
\end{tabular}

Persentase ketuntasan belajar klasikalnya yang diperoleh yaitu $78,26 \%$, dikatakan tuntas., hasil belajar klasikal dapat dilihat pada Tabel 6.

Tabel 6. Hasil Belajar Kognitif Implementasi LKPD Secara Individu

\begin{tabular}{cccc}
$\begin{array}{c}\text { Jumlah } \\
\text { Peserta } \\
\text { Didik }\end{array}$ & $\begin{array}{c}\text { Nilai } \\
\text { Rata- } \\
\text { Rata } \\
\text { Postest }\end{array}$ & $\begin{array}{c}\text { Persentase } \\
\text { Ketuntasan } \\
\text { Belajar Klasikal }\end{array}$ & KKM \\
\hline 23 & $X=81,2$ & $78,26 \%$ & $\geq 75$
\end{tabular}

Ketuntasan Klasikal Belajar : $\geq 75 \%$

Berdasarkan nilai hasil belajar dan ketuntasan klasikal yang diperoleh, menunjukkan bahwa LKPD dapat meningkatkan hasil belajar kognitif siswa. $\mathrm{Hal}$ ini dikarenakan LKPD mampu memberikan pengalaman belajar untuk membangun pengetahuan siswa.

LKPD dikembangan berbasis model pembelajaran Discovery Learning (DL) yang kegiatan pembelajarannya mengacu pada tahapan (sintaks) model DL. Hal tersebut memungkinkan peserta didik memiliki 
kesempatan untuk terlibat lebih banyak di dalam kegiatan pembelajaran. Mulyatiningsih (2013)menyatakan bahwa bahwa model discovery learning mampu menciptakan situasi yang membuat peserta didik aktif dalam pembelajaran.

\section{PENUTUP}

\section{Simpulan}

1) Berdasarkan hasil validasi Lembar Kerja Peserta Didik (LKPD) berbasis Discovery learning dinyatakan layak untuk diuji cobakan kepada peserta didik, hal ini terlihat dari rerata persentase kevalidan sebesar $84,37 \%$ yang termasuk ke dalam kategori sangat valid.

2) Hasil uji coba LKPD menggunakan strategi pembelajaran indoor-outdoorindoor (IOI) menunjukkan bahwa LKPD berbasis DL dapat meningkatkan ketuntasan belajar kognitif peserta didik secara klasikal. Hal ini dilihat dari nilai rata-rata postest 81,2 dan ketuntasan klasikal sebesar $78,26 \%$.

\section{Saran}

1) Sebaiknya sebelum guru menerapkan model DL menggunakan LKPD yang dikembangkan, perlu dipersiapkan dengan baik koordinasi kegiatan pembelajaran pada tahap outdoor dengan peserta didik.

2) Perlu adanya pengenalan lebih luas terkait potensi lokal yang ada yaitu sebagai media pembelajaran di Turtle Learning Center (TLC) Universitas Bengkulu

\section{UCAPAN TERIMA KASIH}

Saya mengucapkan terima kasih khusus kepada oleh tim Partnerships for Enhanced Engagement in Research (PEER) yang telah mendukung dan bersedia berkerja sama dalam penelitian ini.

\section{DAFTAR PUSTAKA}

Iskandar, D.T.. 2000. Kura-kura \& Buaya Indonesia \& Papua Nugini. Bandung: PAL Media Citra.

Depdiknas.2008.Panduan Pengembangan Bahan Ajar SMA/MA.Jakarta: Depdiknas.

Kemendikbud. 2014. Permen-dikbud No 59 Tentang Kurikulum 2013 Sekolah Menengah Atas/ Madrasah Aliyah. Jakarta: Kemdikbud.

Lorena, Mutia. 2018. Pengembangan LKPD Model Discovery Learning Berdasarkan Identifikasi Mangrove di TWA Pantai Panjang Bengkulu. Jurnal Diklabio 3 (1): 59-66(online) (https://ejournal.unib.ac.id/ind ex.php/jppb/article/view/7821/395 9) diakses pada tanggal 11 Juli 2019.

Mar'iska, Ali. 2010. Identifikasi Keanekaragaman Kura-Kura di Sungai Mulus Lubuk Linggau. Jurnal Fauna 10(2): 11-17 (http://repository/jurnal.pdf) diakses 20 Januari 2018.

Mulyatiningsih, Endang. 2013. Metode Penelitian Terapan Pendidikan. Bandung: ALFABETA. 
Munandar, Agung. 2016. Pengembangan LKPD Berbasis Discovery Learning Untuk Meningkatkan Kemampuan Mengukur Dan Memprediksi Pada Pserta Didik Kelas X SMA 11 Purworejo. Jurnal Pendidikan. (http://repository.umpwr.ac.id:pdf) diakses 20 Januari 2018.

Riduwan. 2015. Skala Pengukuran Variabel-variabel Penelitian. Bandung : ALFABETA.

Rifa'i, A. 2012. Psikologi Pendidikan. Semarang: Unnes Press.

Sari, Intan. 2018. Pengembangan Lembar Kegiatan Peserta Didik Untuk Menilai Upaya Konservasi Kura Kura. Jurnal Diklabio 3 (1): 25-31 (online)(https://ejournal.unib.ac.id /index.php/jppb/article/view/7814 ) diakses pada tanggal 11 Juli 2019.

Sugiyono. 2012. Metode Penelitian Kuantitatif Kualitatif dan $R$ \& $D$. Bandung: Alfabeta.

Utami,PS.2015. Pengaruh Belajar dan Metode Pembelajaran Terhadap Hasil Belajar IPA Peserta didik SMP. Jurnal Pendidikan, 2(1): 97-103. (http://journal.uny.ac.id) diakses tanggal 10 Desember 2018.

Widjajanti, Endang. 2013. Kualitas Lembar Kerja Siswa. Jurnal Wahana Pendidikan Kimia, 2(1): 45-46. (http://jurnal.fkip.unila.ac.id) diakses tanggal 10 Januari 2019.
Wiryono. Alif, Y. Z dan Yemie, S. 2016. Pendidikan Konservasi Kura-kura Sumatera Untuk SMA. Bengkulu: Unit Penerbit FKIP UNIB.

Yeni Haryonik. 2018. Pengembangan Bahan Ajar Lembar Kerja Siswa Dengan Pendekatan Matematika Realistik. Jurnal Matematika dan Pembelajaran 6(1): 40-55 (journal.uinalauddin.ac.id/index.ph p/Mapan/article/download/4055/p df.) diakses 23 Juli 2019.

Zukmadini, Alif Y., Bhakti Karyadi., Wiwit Trisnawati. 2018. Strategi Pembelajaran Biologi Berbasis Lingkungan Melalui Kombinasi Pembelajaran Indoor dan Outdoor Sebagai Upaya Meningkatkan Keterampilan Proses Siswa SMA. Prosiding Seminar Nasional Pendidikan Biologi: 148-155. 